\title{
GLOBALISATION AND ITS IMPACT ON CIVIL SOCIETY: PHILOSOPHICAL, LEGAL AND SOCIOLOGICAL ASPECTS
}

\author{
HANNA DUSZKA-JAKIMKO*
}

\section{INTRODUCTION}

'Civil society' is a synthetic term that describes the status of individuals and social groups in a contemporary state. Its ontological ambiguity renders it complex and therefore a subject of interest in many areas of science: political and legal doctrines, social sciences and historical sciences. The literature stresses that the idea of a civil society may be regarded as a normative or descriptive category. ${ }^{1}$ In the first aspect, "using the term "civil society" shall have the purpose of indicating a particular ideal of social order (in a prescriptive meaning - regarding how things should be) and the aforementioned shall take place on the grounds of political philosophy. The descriptive category is positioned within social and political sciences and indicates a particular type of social organization as well as an analysis of social phenomena'2. In the context of both approaches, this study attempts to describe 'civil society' both nationally and globally.

\footnotetext{
DOI: 10.2478/wrlae-2013-0038

* PhD; LLM; Department of Theory and Philosophy of Law, University of Opole. hd-j@wp.pl

${ }^{1}$ Dorota Pietrzyk-Reeves, Idea społeczeństwa obywatelskiego. Wspótczesna debata i jej źródta (Wydawnictwo Uniwersytetu Wrocławskiego 2004) 11. The semantic connotations of the term in question should also be noted, as the term "society" is significantly involved in a sociological way, while the adjective "civil" has a normative meaning. Therefore we receive, as Artur Lawniczak points out, "a sociological and legal terminological mixture", yet, as the author afterwards states, in this term it is not the lexical plane that has the most important meaning - see Artur Ławniczak, 'Społeczeństwo obywatelskie - kilka uwag teoretycznych i konstytucyjnoprawnych' in Jolanta Blicharz and Jan Boć (eds), Prawna działalność instytucji spoteczeństwa obywatelskiego (Kolonia Limited 2009) 33.

2 Justyna Przedańska, Spoteczeństwo obywatelskie jako idea filozoficzna, in Blicharz and Boć (eds) (n 1) 14.
} 


\section{THE CIVIL SOCIETY - PHILOSOPHICAL CONCEPTS (A CONTEMPORARY APPROACH)}

A common denominator of many depictions of civil society dating back to antiquity seems to be 'an independence from authority resulting from the fact that the members of this society dispose of their own means of sustenance, may, want and are able to, in order to fulfil their needs, independently organize themselves' ${ }^{3}$. This statement itself leads to the formulation of a basic concept of civil society. It relates to the opposition between the liberal concept of individualism and the communitarian concept of a community ${ }^{4}$.

Firstly, it is the individual, not the community, that 'constitutes the ontological basis of the civil society' ${ }^{5}$ with independence from the state spheres - public, economic, social or cultural - within which individuals may voluntarily act, creating different social organizations, unions, associations and self-governments. The $17^{\text {th }}$ century theories of liberalism proclaim the absolute value and dignity of the individual over the community, with the happiness of every human being as the purpose of a social organization. Life, liberty and property, derived from natural law concepts, are the basis of the liberal social and political doctrine, the subject of which is 'freedom from oppression by the state for citizens ${ }^{\prime}$. The subject always comes first in relation to the aims, and as J. Rawls' theory states, the identity and the aims may be freely chosen or rejected ${ }^{7}$. Also, the post-modern perspective offers a similar view, relating to the concept of a 'strengthened individual', treating the individual autonomously in the planes of both law and social conscience $^{8}$. The society in the liberal theory is a set of individuals, entirely

\footnotetext{
${ }^{3}$ It is also worth pointing out that Aristotle related to civil society indirectly, and the grounds for contemporary social thought - having both a left-wing source (Hegel, Marx), as well as the social teachings of the Catholic Church (Thomism) - were laid and developed by such thinkers as J. Locke, D. Hume, G. W. Hegel, Ch. A. Tocqueville, A. Gramsci, K. Marks, K. Popper; see Europa i spoteczeństwo obywatelskie. Rozmowy w Castel Gandolfo (Wydawnictwo Znak 1994); Ani książe, ani kupiec: obywatel. Idea spoleczeństwa obywatelskiego $w$ myśli współczesnej, Introduction and selection by Jerzy Szacki, (Wydawnictwo Znak 1997); Jakub Szlachetko, 'Konstytucyjne wolności, prawa i obowiązki obywatela a idea społeczeństwa obywatelskiego' 4 Zeszyty Naukowe "Disputatio" ('Społeczeństwo obywatelskie') 15.

4 See Adam Chmielewski, Spoleczeństwo otwarte czy wspólnota? (Wydawnictwo Arboretum 2001); Lech Morawski, Główne problemy współczesnej filozofii prawa. Prawo $w$ toku przemian ( $3^{\text {rd }}$ edn, Lexis Nexis 2003) 165ff; Pietrzyk-Reeves (n 1) 17ff; Przedańska (n 1) 14.

${ }^{5}$ For more on the originality of the individual in relation to the community see Nina Gładziuk, 'Komunitaryzm' in Paweł Kaczorowski (ed), Nauka o państwie (Oficyna Wydawnicza SGH 2006), 157ff; Przedańska, (n 1) 15.

6 Giovanni Sartori, Teoria demokracji, Piotr Amsterdamski, Daniel Grinberg (trs) (Wydawnictwo Naukowe PWN 1994) 466.

${ }^{7}$ It is also worth mentioning that this attitude is criticized in the literature, as the individual does not create aims, but at the utmost discovers them, as 'there is no possibility of distinguishing a person from the aims and identity that constitute this person', see Gładziuk (n 5) 157.

8 For more see Joanna Helios, Wioletta Jedlecka, 'Jednostka czy wspólnota? Postmodernizm w prawie europejskim’ in Michał Błachut (ed), Z zagadnień teorii i filozofii prawa. Ponowoczesność (Wydawnictwo Uniwersytetu Wrocławskiego 2007) 268-269.
} 
autonomous and voluntarily forming groups in order to achieve their own or common interests.

Secondly, it is the state - in the liberal perspective of a neutral (not engaged) state - that must safeguard the rights and interests of the individual, ensure the personal inviolability and personal property thereof, not interfere in economic activity, ensure freedom to make individual choices limited only by the rule of law (vis à vis the economic laissez-faire concept of the state regarded as the 'night watchman'). Therefore, according to the communitarians, the state relinquishes the power to create political aims that form the beliefs of an individual, such as community ideals and traditions, and the freedom to cultivate personal, social and religious values.

In the doctrine of communitarianism the citizen is perceived in relation to the community and its welfare, there is no alienation of individuals from the state, and the citizens (i.e. the community) cooperate with the state, promote common moral values, with the goal of fulfilling the common good. The role of the state is to safeguard the values on which the identity and integrity of the community depend. The credo of a community is loyalty to tradition, authority and shared values, customs, a just social order and legal security. The individual is considered a product of the society. The communal attitude is characterised by the bonds (as formulated by F. Tönnies 'natural will'9) that ensure its homogeneity based on respect for authorities, tradition and customs. According to communitarians, an individual cannot be divided from connections and affiliations that exist socially, or the individual would lose its 'integrative me' ${ }^{10}$. The theory of communitarianism places the idea of the civil society in the legal sphere, but also finds it instrumental for social and cultural purposes. Ideally, the society is a community, within which individuals exist and realize their own aims; however, communitarianism opposes the liberal concept of an individual as 'socially not detailed and not determined, not anchored in values and practices of the community and therefore not situated permanently anywhere' ${ }^{11}$. For communitarians, the community recognizes the sociological bonds that have been cultivated by society, the common traditions and customs that have been developed, and respect for history and prevailing authorities (regarding which communitarians derive from the ideas of Alexis de Tocqueville). Simultaneously, concern for the realization of the 'rational will'" (contractual, political), based on the active participation of citizens in political and public life in such fora as local associations and unions, fostering pro publico bono ethics (see John Locke's 'associative', organized understanding of the term 'civil society') becomes important.

The doctrine of commutarianism does not address the question of where the community should be positioned: whether at the level closest to the individual (natural, traditional, sociological), i.e. in the family,

\footnotetext{
${ }^{9}$ Ferdinand Tönnies, Wspólnota $i$ stowarzyszenie ( $2^{\text {nd }}$ edn, Wydawnictwo Naukowe PWN 2008) quoted from: Hubert Izdebski, Fundamenty wspótczesnych państw (LexisNexis 2007) 27.

${ }^{10}$ Gładziuk (n 5)158.

11 ibid.

${ }^{12}$ Tönnies (n 9) 28.
} 
neighbourhood, professional corporation, or rather at the political level that includes the civil society of voluntary organizations and associations, the state, or perhaps as a global community. The answer to this question may be sought in the idea of natural will, which relates to the idea of community as a tradition, as well as rational will related to unions or associations (as in Aristotle's 'political community'), in which law - civil, i.e. law related to citizens - was the basic bond. The answer could also be found in Hegel's relations between what is private and what is public, as the civil society in this depiction is an intermediate clause, acting in the sphere of economical and social relations, beyond the sphere of direct interest of the state, allowing the free initiative of the citizen ${ }^{13}$.

Commutarianism seems to place an individual in a 'pluralistic network of communities ${ }^{14}$ that combines the traditions of natural and rational will, granting the individual many memberships and social roles, favouring personal activity and the right to self-organization, allowing conscious determination of social aims, rationality of undertaken actions that serve the achievement of personal aims and provoking social participation in decision-making processes without the impulse or control of state authority ${ }^{15}$. Therefore, it promotes both conservative and liberal values and respects both traditional and modernistic views. It may be even stated that the grounds of communitivity based on natural will consist in associative communitivity, which does not exclude the individual's individuality. Therefore, it is very important that communitarianism is not achieved by forceful means (which may produce a totalitarian doctrine) ${ }^{16}$. Contemporary societies, being often culturally and ethically diverse, have to respect the subjectivity of each free, autonomous and independent individual in a community. Thus the civil society safeguards 'those elements of social life that do not belong to the state (...) and realize the spontaneous non-political activity of citizens and fulfilling non-political needs of people ${ }^{17}$. It is also a society in which there is a 'beyond-government' area of common life located outside the domain of activity of public authorities (although regulated and controlled by those authorities and law ${ }^{18}$ ). In such a society, citizens individually and voluntarily - without compulsion - create according to their needs forms of social, professional, economic and cultural life (e.g. the 'third sector', which is comprised of non-governmental organizations), and consciously participate in social and decision-making processes. It should be stressed that in the context of continental legal cultures, the idea of civil society emphasizes the independence of social life from public authorities.

\footnotetext{
${ }^{13}$ Izdebski (n 9) 60.

${ }^{14}$ ibid 166.

${ }^{15}$ For more see Jan Hartman (ed), Stownik filozofii (Wydawnictwo Zielona Sowa 2004) 208; also Grażyna Skąpska, 'Prawo i społeczeństwo: teorie systemowe w socjologii a koncepcje społeczeństwa aktywnego' in Prawo $w$ zmieniajacym się społeczeństwie (Wydawnictwo Adam Marszałek 1992) 73.

${ }^{16}$ Special attention is paid to the issue by Lech Morawski (n 4) 182.

17 Wojciech Sokolewicz, 'Rozdział I „Rzeczpospolita”, artykuł 12' in Leszek Garlicki (ed), Konstytucja Rzeczpospolitej Polskiej. Komentarz, vol. V (Wydawnictwo Sejmowe 2007) 11.

${ }^{18}$ Izdebski (n 9) 60.
} 
Anglo-Saxons view civil society as a synonym for state institutions that are publicly active, pluralistic, and that participate in the creation and fusion of political and social life according to the state's agendas. The goal is to combine different social groups (social pluralism) in order to enable them to act in organizations and structures (associations) that serve the accomplishment of different interests and aspirations, including those related to the decisions of bodies of state authority ${ }^{19}$. Such a standpoint is based on the idea of society as 'the personal political subjectivity of an individual and its equal, constitutionally guaranteed rights ${ }^{20}$.

It should be emphasized that the basis of any discussion of civil society should be individual self-realization with the freedom (with a normatively and socially determined own identity ${ }^{21}$ ) to undertake initiatives and participate in social, public, cultural and associative activity ${ }^{22}$. An individual should be vested of reason and will, "capable of making rational choices in collective life, in which an individual's interest and welfare cocreate the common good"23. Reason and free will also enable the individual to adopt a critical standpoint regarding the state and institutions managing public affairs, which in turn gives a guarantee of public order ${ }^{24}$.

According to J.Przedańska a human is by nature a 'social being' who cannot live beyond the community and the state, unable to dispose of the "integrative me", and should therefore be a subject of statehood ${ }^{25}$. This subjectivity (expressed mostly by the depiction of society as equal in relation to the state as a political organization) is based on the principle of social participation in making decisions of a public and national character, with the goal of creating values and norms common for the state and society. Methods of adopting and executing law need not be imperative and unilateral. Rather, it is within the legislative and judiciary means of state bodies to adopt consensual, negotiable regulations that guarantee the influence of private citizens on the content of adopted norms. This method favours horizontal, pluralistic techniques of solving legal conflicts over unilateral imperatives.

In the doctrine of constitutional law it is held that the idea of civil society gains full meaning only when combined with the principle of

\footnotetext{
${ }^{19}$ Leszek Garlicki, Polskie prawo konstytucyjne. Zarys wykładu (4 ${ }^{\text {th }}$ edn, Wydawnictwo Liber 2000) 66.

${ }^{20}$ Sokolewicz (n 17) 3.

${ }^{21}$ For more see Helios, Jedlecka (n 8) 271.

${ }^{22}$ See Constitutional Tribunal's verdict from May 27, 2003 ref. symbol K 11/03, in which the Tribunal clearly states that civil society is 'a society of free, conscious, active and engaged in public affairs citizens (...) There is no area of public life in which citizens organized in social organizations or foundations are not involved' -author's translation HD-J; see also Krzysztof Murawski, Państwo i spoleczeństwo obywatelskie: wybrane problemy rozwoju demokracji w Polsce 1989-1997 (Wydawnictwo Adam Marszałek 1999); Prawo $i$ ład społeczny. Księga Jubileuszowa dedykowana Profesor Annie Turskiej (Wydawnictwo Uniwersytetu Warszawskiego 2000).

${ }^{23}$ See Anna Turska, 'Państwo i społeczeństwo' in Anna Turska (ed), Refleksje o państwie, prawie i społeczeństwie (C. H. Beck 2005) 146.

24 ibid 148.

${ }^{25}$ Przedańska (n 1)16.
} 
subsidiarity ${ }^{26}$ of the state, strengthening social entitlements and encouraging public activity by the citizens and their communities. The principle of subsidiarity presumes the priority, independence and autonomy of individuals in fulfilling their needs before fulfilling those of social groups (communities), especially before the fulfilment of the state's needs as the 'supreme community' and the state's activity in creating the individual's freedom. The state as the supreme community, notes P. Winczorek, 'should not substitute lower-ranking communities, e.g. associations, municipalities, families, in fulfilling their justified needs (material, cultural, protective etc.), unless the aforementioned communities cannot meet their own needs. Higher ranking communities should then assist (Latin: subsydium) lower ranking communities ${ }^{27}$. Therefore, all matters concerning an individual should be decided on a level as close to the person in question as possible. This is the basis of the constitutional model of self-government, and assumes a broad self-governmental authority and presumption of competence in favour of territorial communities. The principle of subsidiarity and the autonomy of the individual should thus safeguard against excessive interventionism by the state.

The principle of subsidiarity is an expression of individuals' independence and autonomy, their activity and responsibility for social and political actions, while limiting the powers and tasks of the state for which direct intervention is treated as a last resort; thus, this rule is to guard against the excessive intervention of the state. Subsidiarity, therefore, as M. Granat noted, "is the basis for creating conditions for citizens' actions, but in a way that does not violate the public interest and does not exclude the possibility of intervention of authority". The doctrine of constitutional law, as the author continues, sees the principle of subsidiarity as a rule designating the relationship between the political state and civil society, including state interference in society, which does not exceed the limits necessary to protect the public interest.

In modern times the idea of the civil society is realized in democratic regimes and is based on the idea of a responsive community that can fulfil both individual and group needs. This democratic model would be exemplified by:

a) respect for the cultural and ethnic traditions of a community, determined by the "natural will",

b) existence of a horizontal arrangement of relations between citizens and public authority, based on such principles as respect for human dignity, equality before the law, equal opportunity for each individual, prohibition of discrimination and enfranchisement,

c) realization of the 'rational will' of the community as manifested in the functioning of non-governmental, voluntary social organizations,

\footnotetext{
${ }^{26}$ The only normative basis of the principle of subsidiarity may be found in the Introduction to the Constitution of the Republic of Poland of April 2, 1997 (Journal of Laws No. 78, pos. 483) which, as the literature notices, does not interfere with recognizing its normative character and refer to it in judicial decisions, see Leszek Garlicki, 'Wstęp' in Leszek Garlicki (ed), (n 17) 21. On the relation of the principle of subsidiarity with the idea of the civil society see the resolution of the Supreme Administrative Court from December 12, 2005 ref. symbol II OPS 4/05; see also Sokolewicz (n 17) 33.

${ }^{27}$ Piotr Winczorek, Wstęp do nauki o państwie (3 $3^{\text {rd }}$ ed., Wydawnictwo Liber 1998) 116.
} 
d) change from the imperious form of legal system in which laws are adopted unilaterally to a democratic legal system that requires a consensus among state bodies, citizens and their associations ${ }^{28}$.

e) Today's literature indicates three main trends in the understanding of civil society ${ }^{29}$ :

a) the sociological trend, emphasizing social self-organization and citizens' actions independent from national structures; the state, however, should set frameworks for those actions. Those frameworks, within a democratic state, are indicated by regulations included in constitutions; some of them directly address the concept of civil society, while others indicate legal institutions creating social undertakings.

b) the procedural trend - civil society means respecting procedures and measures of

c) publically expressing beliefs and opinions (debates, compromises). The frameworks for social actions in the procedural trend are created by the ethics of communication.

d) the axiological trend, whose object of interest are values, norms and opinions, such as pluralism, tolerance, collective solidarity and rule of law, and symbolic action.

It is the procedural trend which best illustrates the contemporary vision of society.

In the conditions of growing autonomy of the civil society (its emancipation) and the increase in complex issues of local importance, the procedural trend seems to address the current problems of building civil society. To build a civil society, it is necessary to trigger its activity. This trend creates organizational structures and procedures that are conducive to achieving social objectives, negotiations and concluding agreements. The development of civil society is also influenced by the decentralization of state power and transfer of its authority to regional and local political units, along with delegation of powers to social organizations and institutions such as associations, trade unions, foundations and citizens' initiatives which represent social concerns. In social interactions, the state should be a partner coordinating mutually agreed undertakings, rather than a directly controlling supervisor. Thus it seems that the procedural trend corresponds with the idea of communicative action developed by J. Habermas and the idea of the systemic approach to law, as "both concepts put the main emphasis on negotiation mechanisms and agreements in the processes of functioning of law; the bases for those concepts, however, are substantially different." 30

The concept of communicative action has already been substantiated by the ethical necessity to comply with the rules of honest communication and to extend the autonomy of the individual, whereas the systemic

\footnotetext{
${ }^{28}$ See more: Ewa Kustra, 'Władczy oraz negocjacyjny typ tworzenia prawa. Szanse i zagrożenia’ (1994) 4 Ruch Prawniczy, Ekonomiczny i Socjologiczny $23 \mathrm{ff}$.

${ }^{29}$ See Maria Magoska, Obywatel w procesie zmian (Wydawnictwo Księgarnia Akademicka 2001); Maria Magoska, 'O idei partycypacji społecznej w budowie społeczeństwa obywatelskiego' in Prawo $w$ zmieniajacym się spoleczeństwie (Wydawnictwo Adam Marszałek 1992) 279-284.

${ }^{30}$ Lech Morawski, 'Spór o model polityki prawa - ujęcie systemowe' (1992) 9 Państwo i Prawo 35-37.
} 
approach sees negotiations as an instrument of maintaining the social systems' abilities of self-organization and self-steering.

In times of globalization, social activity, particularly at the local level, offers opportunities for the development of a civil society engaged and involved in solving social issues. Civil society in a democratic state allows the fulfilment of individual aims alongside those of groups and the community, and fosters interest and participation in public, political and social life (functioning in a state of non-governmental organizations national in character, different social movements, territorial self-government, the guarantee of observance and realization of respect for individuals' rights and freedoms is an expression of pluralistic aspirations of society and democratization of public life). Although the civil society is a 'rank and file initiative' ${ }^{31}$, a democratic state, having a legal infrastructure and institutions specifically focused on the protection of citizens' rights has the task of safeguarding the freedom of individuals to develop their active participation in public life on their own terms.

\section{THE CIVIL SOCIETY - LEGAL GROUNDS OF ACTIVITY}

The doctrine of law is the cornerstone of the concept of the civil society and should therefore be regarded as the basis of a legal community $^{32}$, the purpose of which is the protection of citizens' rights to participation in decisions on the division of public tasks and methods of performing them, recognizing that it is the law that constitutes the basic institution of agreement between society and state authorities.

The following should be regarded as the normative prerequisites of activity of civil society, according to the provisions of the Constitution of the Republic of Poland of April 2, 1997: consideration of the Nation as the sovereign (article 4), respect for the natural dignity of the human being (article 30), creation of a broad area of freedoms and civil rights and the existence of institutions that effectively guarantee the observance thereof (the right to compensation for damage resulting from the illegal activity of bodies of state authority - article, $77 \mathrm{sec} .1$, the right to appeal against judgements and decisions delivered in the first instance - article 78, the institution of the constitutional complaint - article 79 , the right to address the Ombudsman - article 80), the right of recourse to a court (article 45 and 77 sec. 2), equality of all people before the law (article $32 \mathrm{sec} .1$ ), the prohibition of discrimination in political, social and economic life (article 32 sec. 2). The vision of the civil society in the legal order is developed by such standards as: respect for personal, suffrage, and social rights stipulated in Chapter II of the Constitution of the Republic of Poland, freedom of conscience and religion, the existence of freedom of speech as grounds for democracy accompanied by the possibility of adopting a critical standpoint against state institutions that manage public affairs, protection of privacy, and a developed market economy as the basis for the economic system. It

\footnotetext{
${ }^{31}$ See Szlachetko (n 3) 20.

${ }^{32}$ Immanuel Kant, Odpowiedź na pytanie: Czym jest oświecenie?, Tomasz Kupś (tr) in Rozprawy z filozofii historii (Wydawnictwo Antyk 2005) quoted from: Przedańska (n 1) 21.
} 
should be noted, however, that in the Polish legal system the principle of the civil society has not been formulated expressis verbis in the text of the Constitution. The grounds for these ideas are contained collectively in article 12 of the Constitution of the Republic of Poland, which ensures freedom for the creation and functioning of voluntary, non-political and non-profit organizations and foundations able to achieve various social interests and the aforementioned principle of subsidiarity, as stipulated in the Preamble to the Constitution.

In Poland, the constitutional institutions that comprise the legal framework that authorizes social activity and collective actions, designed to influence the policy of the state are: 1) freedom of association ${ }^{33}$ (articles 12 and 58); 2) freedom of assembly ${ }^{34}$ (article 57); 3) freedom of association in trade unions, social and professional associations and organizations of employers $^{35}$ (article 59), self-governments of territorial, professional and economic character; 4) freedom to create religious associations (article 53). Among the other rights of a civil society, the following should be highlighted: 1) the right of suffrage and to participate in referendums ${ }^{36}$ (article 62); 2) the right of legislative initiative ${ }^{37}$ (article 118 sec.2); 3) the right to obtain information on the activities of bodies of public authority as well as persons discharging public functions ${ }^{38}$ (article 61); 4) the right to submit petitions, proposals and complaints (article 63). The freedom to create and the functioning of political parties (articles 11 and 13 of the Constitution) as components of civil society remain unresolved issues. Social organizations function with a presumption that they shall not assume, wholly or partially, power in the state; they are created to represent the different interests of citizens, so depending on their programme and character they may only influence the process of making political decisions, which seems to be contradictory to the basic aims of political parties ${ }^{39}$. However, the value of freedom of functioning of political parties is stressed in both the literature and judicial decisions of the Constitutional Tribunal as crucial in determining the factual and effective shaping of the political structure in a pluralistic democratic society ${ }^{40}$.

33 Besides the constitutional regulations, the issue of creation and functioning of associations is regulated by the Act of April 7, 1989. Law on Associations, uniform text, Journal of Laws 2001, No. 79, pos. 855 as amended, and the Act of April 6,1984 on Foundations, uniform text, Journal of Laws 1991, No. 46, pos. 203 as amended.

34 The limitations regarding the freedom of assemblies are regulated by the Act of July 5, 1990 Law on Assemblies, Journal of Laws 1990, No. 51, pos. 279 as amended.

35 See Act of May 23, 1991 on Trade Unions, uniform text, Journal of Laws 2001, No. 79, pos. 854 as amended; Act of May 23, 1991 on Organizations of Employers, Journal of Laws 1991, No. 55, pos. 235 as amended.

${ }^{36}$ See Act of March 14, 2003 on National Referendum, Journal of Laws 2003, No. 57, pos. 507 as amended.

${ }^{37}$ See Act of June 24, 1996 on the Execution of Legislative Initiative by Citizens, Journal of Laws 1999, No. 62, pos. 688 as amended.

38 Act of September 6, 2001 on the Access to Public Information, Journal of Laws 2001, No. 112, pos. 1198 as amended.

${ }^{39}$ See Act of June 27, 1997 on Political Parties, uniform text, Journal of Laws 2001, No. 79, pos. 855 as amended; See Sokolewicz (n 17)12-13.

40 Marzena Kordela, Zarys typologii uzasadnień aksjologicznych $w$ orzecznictwie Trybunału Konstytucyjnego (Wydawnictwo Branta 2001) 61-62. 
Not only criteria are critical in shaping the ideas of the civil society, but also other significant factors need to be considered in providing the cultural basis for such a society. A cultural community demands tolerance, openness and social activity for the common good (an avoidance of learned helplessness); the opportunity to undertake (individual and group) initiatives and assume responsibility for them; the desire to obtain knowledge concerning the most important decisions undertaken by bodies of public authorities; the will to cooperate with the members of a given community; the social trust that facilitates work in groups. A strong emphasis is put on rationality, innovation and creativity in solving social problems. An important feature, one which is an essential part of civility, is the ability to communicate, which means the possibility to participate in discourse regarding public affairs, the ability to mediate and to find rational compromises ${ }^{41}$. Another important condition that favours the development of a civil society is a strongly developed 'third sector' in the state comprised of non-governmental organizations of different kinds (associations and foundations) and an effectively functioning local self-government. Moreover, equal opportunity for all members of society to succeed is important, leading to the desired horizontal arrangement of relations between them - each individual has the same dignity, equal rights and obligations and freedom of activity (regardless of race, religion or disability).

A change from imperious forms of normative regulations to negotiable, consensual forms takes place when hierarchical systems of creating law are substituted or supplemented by consensual procedures that function horizontally. This often results from contemporary economic factors such as the openness, decentralization and liberalization of national economies and financial markets as well as the everyday life of individual people $^{42}$. An increase in the significance of contracts, agreements and settlements at the cost of unilateral, imperious legal solutions is characteristic of a horizontal structure. Cooperation and consensual forms of conflict resolution take the place of top-down communication, substituting it with a culture of dialogue and horizontal communication ${ }^{43}$. Decisions of public authority, devoid of arbitrariness and seen as a result of compromise and cooperation, are able to meet the needs of individuals and their communities. The belief that actions within the public sphere are in the citizens' best interest is strengthened by the decentralization of authority and active functioning of local self-government.

Therefore, in a national state the idea of the civil society relates to national traditions, legal culture and normative values; to the rule of law, in which the freedom, dignity and equality of individuals before the law are regarded as primary values; to the constitutionally defined standards of justice and rightness as the basic values for legal culture; to the principles included in documents and the doctrine of human rights and the principles

\footnotetext{
41 Turska (n 23) 152.

42 Zdzisław Brodecki, Krzysztof Łokuciejewski, 'Globalizacja' in Jerzy Zajadło (ed), Leksykon wspótczesnej teorii i filozofii prawa. 100 podstawowych pojęć (C. H. Beck 2007) 105.

43 See Jolanta Jabłońska-Bonca, 'Prawnik jako negocjator $-\mathrm{z}$ problematyki retoryki interpersonalnej' (2001) 3-4 Studia Prawnicze 138.
} 
of international law; to the values of the common good, good customs; to conformity with universally recognized moral precepts and principles of social coexistence.

Both legal and non-legal factors should therefore establish public discourse as one of the most important determinants of the civil society. Owing to private ownership and freedom of competition, the development of political parties, associations and trade unions and cultural and educational institutions or local self-governments, the ideal of the civil society is realized and the citizen is given the sense of participation in relations with the state and governmental organizations ${ }^{44}$.

\section{THE CIVIL SOCIETY - CHALLENGES OF GLOBALIZATION}

Globalization affects the concept of civil society, as it can no longer be considered only in the context of a state's governing initiative but must now be evaluated using supranational criteria ${ }^{45}$. Globalization as a process appropriates both individual as well as public social space, creating a transnational space that 'negates the existence and functioning of societies within the closed space of national states ${ }^{46}$. Thus it is worth questioning the meaning and usefulness of the concept of the civil society as it transcends national boundaries in the age of globalization and integrative processes. Individuals will now need to respect common interests, as they create multinational communities. As consumers they will now need to recognize new spheres of influence and widen their 'sense of citizenship' and 'sense of community' to include the authority of other governments outside their comfort zones.

Globalization affects many aspects of humanity - technological, political, economical, ecological, theological, social, cultural, normative, etc. ${ }^{47}$ - as a result of the intensive increase of international trade, information exchange and foreign investment. Globalization is a network of correlations $^{48}$ influencing the increasingly strengthening relations between the state, transnational and integrative processes and the different areas of human activity realized above and beyond the borders of national states and previously impassable political boundaries. Globalisation is a process of gradual change from independent national economies into one economic

\footnotetext{
${ }^{44}$ Anna Musiał, Dylematy społeczeństwa obywatelskiego

$<$ http://www.racjonalista.pl/kk.php/d,64/q,Spoleczenstwo $>$ accessed 22 October 2010.

45 ibid, 32-35; see also Szymon Ossowski, 'Globalne społeczeństwo obywatelskie - utopia czy realna perspektywa na przyszłość' in Jacek Sobczak and Roman Bäcker (eds), Europejska myśl polityczna wobec globalizacji. Tradycja $i$ wyzwania współczesności (Wydawnictwo Naukowe Ibidem 2005) $71 \mathrm{ff}$.

46 Katarzyna Marzęda, 'Globalizacja a globalne społeczeństwo obywatelskie' in Jacek Sobczak and Roman Bäcker (eds) (n 45) 36.

47 Roman Tokarczyk, 'Prawo natury a postępy globalizacji' in Maria Zmierczak (ed), Prawo natury $w$ doktrynach polityczno-prawnych Europy (Wydawnictwo Naukowe UAM 2006) 147.

${ }^{48}$ See Czesław Mojsiewicz, 'Rozwój procesów o charakterze globalnym' in Jacek Sobczak and Roman Bäcker (eds) (n 45) 3; see also Urszula Kurczewska, 'Globalizacja' in Paweł Kaczorowski (ed) (n 5) 345-347.
} 
organism - a global market of goods and services. It is a process of increasing integration and correlation between states, organizations and transnational establishments that operate globally.

The phenomenon of globalization creates 'public space, in which meanings are created and negotiated, which is located beyond the reach of local existence ${ }^{49}$. Globalization is a complex and ambiguous term which affects almost all aspects of social life ${ }^{50}$, e.g. communication (unfettered migration), telecommunications (Internet), economy and finances, policy (political correlation of states resulting from economic integration), new technologies, mass culture (diminishing the role of tradition and cultural factors within the cultural plane, a cosmopolitan global culture, 'McWorld' ${ }^{51}$ ) and political (military), ecological and social safety ${ }^{52}$. Globalization is, according to Z. Bauman, 'a multidimensional series of social processes that creates, multiplies itself, starts and intensifies a social exchange and correlation on a global level, while at the same time it creates an increasing sense of association between what is local and what is distant ${ }^{53}$

Globalization influences not only economic or political processes, it also penetrates all cultures and social systems of the modern world ${ }^{54}$. Commonly, however, the essence of globalisation processes is viewed as change related to scientific and technological development, and international competition; it is change that influences the industrial social organization, social situations and attitudes, and the values, actions and cultural models to which individuals relate.

The multi-faceted nature of globalisation results from the fact that statutory law is inseparably bound with the changes occurring in the modern world and society under the pressure of globalization.

The formation of the European Union is a good example of the complexity of globalization, where laws, land boundaries and economic factors have changed the whole face of civil society. Globalization means integration both in the institutional, as well as ideological and political aspect. In the legal aspect, globalization does not result in a uniform, common legal culture or a global legal system. It influences the existing

\footnotetext{
49 Jerzy Leszczyński, 'Dogmatyki prawnicze w dobie globalizacji' in Jerzy Stelmach (ed), Filozofia prawa wobec globalizmu (Wydawnictwo Uniwersytetu Jagiellońskiego 2003) 122.

50 See Marzęda (n 46) 28, 34.

${ }^{51}$ Benjamin Barber, Dzihad konta McŚwiat (Wydawnictwo Muza 2005).

${ }^{52}$ Zdzisław Brodecki, Krzysztof Łokuciejewski, 'Globalizacja' in Jerzy Zajadło (ed) (n 42) 103.

53 Zygmunt Bauman, Globalizacja, Ewa Klekot (tr), (Państwowy Instytut Wydawniczy 2000) 132. Regarding the other meanings of the term 'globalization' see e.g. Katarzyna Gilarek, Państwo narodowe a globalizacja - dynamika powstawania nowego tadu, (Wydawnictwo Adam Marszałek 2004); Joseph E Stiglitz, Wizja sprawiedliwej globalizacji. Propozycje usprawnień (Wydawnictwo Naukowe PWN 2007); Sobczak and Bäcker (eds) (n 45); Anna Bąkiewicz (ed), Gospodarka i społeczeństwo $w$ dobie globalizacji, (Wydawnictwo Dialog 2000); Marek Pietraś (ed), Oblicza procesów globalizacji (Wydawnictwo UMCS 2002).

${ }^{54}$ See more Janusz Guść, Krzysztof Łokuciejewski, Globalizacja a jurydyzacja. O wptywie globalizacji na skale prawotwórstwa $w$ liberalnym państwie demokratycznym in Jerzy Stelmach (ed) (n 49) 27-37; also Mark van Hoecke, European legal cultures in a context of globalisation in Tomasz Gisbert-Studnicki, Jerzy Stelmach (eds), Law and legal cultures in the $21^{\text {st }}$ Century - Diversity and Unity (Wolters Kluwer 2007) 82-93.
} 
normative systems, penetrates national cultures, recognizes multiculturalism and requires new patterns of behaviour for participants in legal systems. It seems that the effect of the development of new, common cultural bonds may be diminishing with the threat of international conflicts determined by differences in cultures, national traditions and influences.

Globalization requires a generalization (unification) ${ }^{55}$ of legal standards regarding creating and executing unified legal rules within the areas of jurisdiction of different countries. In modern times, coexistence of different legal dimensions - national, international or regional law - is a contemporary feature of legal systems. A process of 'detachment' of the law from the state, which leads to legal norms on a global scale, is an effect of such changes. The literature points to a response to the "peripherality of law and legislature, bond with regional cultures and the needs of local environments ${ }^{56}$. Understanding of international political and economic relations and the necessity of closer cooperation between supranational organizations (including NGOs) may limit each state's sovereignty and require new ways to enforce laws on a particular territory. The way the state has functioned as a sovereign territorial community is subjected, in the age of globalization, to a significant evolution. More and more a state 'selflimits its own independence and avoids the challenges of globalization by using the "protective umbrella" of international economic and military agreements' ${ }^{57}$. Therefore, the conventional understanding of society's role within state structures is subjected to transformations, and the changes required by globalization in the organization and functioning of modern states question the usefulness of a positivist paradigm of the state and law. The law may now be created by supra-state structures (e.g. the European Union), on a global, regional and local scale, it may be executed beyond the state, and legal disputes may be decided on by other bodies than the state's courts. The centre of gravity is therefore moved from the law as a 'product' of the will of the state to the law regarded as a contract between individuals (which are usually large international corporations). Norms and decisions, as G. Skapska states, become increasingly subjected to the results of different expert analyses, polls and surveys as well as particular claims and interests. ${ }^{58}$. Globalization is also the reason for the creation of so-called soft $l a w^{59}$, as opposed to traditional legislation, where the reference is to the state's means of compulsion. In this scenario, the law does not consist only in an obligatory expression of orders. Instruments that, while not being directly used in courts and tribunals, have practical effects, are referred to as

\footnotetext{
${ }^{55}$ In the literature it is possible to find different terminological approaches related to the mutual approach of legislation, see more Hanna Duszka-Jakimko, Jurysdykcja krajowa w sprawach cywilnych $i$ handlowych $w$ polskim systemie prawnym $i w$ prawie europejskim (Wydawnictwo Uniwersytetu Opolskiego 2006) 123-125.

${ }^{56}$ Andrzej Bator, Globalizacja jako perspektywa postrzegania prawa in Joanna Helios (ed), $Z$ zagadnień teorii i filozofii prawa. Autonomia prawa ze stanowiska teorii i filozofii prawa, (Wydawnictwo Uniwersytetu Wrocławskiego 2003) 24.

${ }^{57}$ Brodecki, Łokuciejewski (52) 105.

${ }^{58}$ Skąpska (n 15) 72.

59 More on the contemporary meaning of soft law see Paweł Skuczyński, Soft law w perspektywie teorii prawa in Olgierd Bogucki, Stanisław Czepita (eds), System prawny a porzadek prawny (Wydawnictwo Uniwersytetu Szczecińskiego 2008) 325ff.
} 
soft law. They are non-binding rules and their legitimacy is based not on formalism, but on compromise and consent ${ }^{60}$.

In the literature it is noted that globalization also influences the traditional system of powers in a state, as 'a classic tri-division of powers comprised of the legislative, executive and judicial should be in this context supplemented by a triad comprised of large international corporations, mass media and the civil society ${ }^{61}$. The history of a society is inseparably bound with history of the state as an organization; what is more, it is stressed that a democratic regime creates a normative framework for the existence of a civil society. Regarding the vast arsenal of constitutionally guaranteed legal instruments, it should be also noted that the idea of the civil society is close to the democratic state. As Marek Safjan writes, 'there is no state without civil society; there is no civil society without common responsibility for a common fate' ${ }^{62}$. Therefore, 'an obligation to think in categories of common good, rationality and predictability of means used, as well as to maintain the proper preferences in the sphere of the hierarchy of values and aims' must be present ${ }^{63}$.

\section{CONCLUSION}

Globalization also results in a change of social relations from vertical to horizontal, focusing on the importance of the individual's autonomy. Therefore, in the age of autonomy, the uniformity of national societies tends to diminish under the influence of supranational transformations, and a global society is shaped in which trans-border and transnational influences on state structures and global mass culture are being developed ${ }^{64}$. The literature indicates that an internal identification with the nation (natural will) withdraws in favour of an external identity, based on the awareness of international relations of competition, supranational systems of communication and contents of symbolic culture ${ }^{65}$. The ease of communication in many aspects of life (professional, personal, residential, social) beyond a national state reduces identification with a state alone (nationality).

Social focus concentrates on global issues mainly due to their 'subjective, time or spatial distance' from an individual or local group, the modern human being as a consumer (which is the main source of satisfaction and a regulator of social processes) and the reluctance to realize the 'rational will' - forming supra-state associations and organizations that aid other individuals or groups. Furthermore, the media transforms national aims into global aims, e.g. humanitarian aid for areas affected by natural disasters, global programmes of environmental and climate protection, and health programmes. Possibly, it also changes the way people perceive

\footnotetext{
${ }^{60}$ ibid 326.

61 ibid 106.

${ }^{62}$ Marek Safjan, Kilka refleksji o kondycji demokratycznego państwa prawa in Władysław Czapliński (ed) Prawo w XXI wieku. Księga pamiątkowa 50-lecia Instytutu Nauk Prawnych $P A N$ (Wydawnictwo Naukowe SCHOLAR 2006) 723.

63 ibid 724.

${ }^{64}$ Paweł Sarnecki (ed), Prawo konstytucyjne RP (7 $7^{\text {th }}$ edn, C. H. Beck 2008) 11.

${ }^{65}$ Helios, Jedlecka (n 8) 272.
} 
citizenship, from national to universalistic, spreading beyond the reach of the national state and connecting with other forms of group membership. Such memberships are more scattered, deprived of common culture, tradition, history and language, yet offering multi-cultural forms of group memberships, perspectives, attitudes and models of life.

Therefore, the global perspective creates the so-called 'multicomponent identity' 66 of individuals striving to determine, first of all, their own individual identities, by the possibility of making choices that are moral and political in character ${ }^{67}$. On one hand, the new identity features strong individualization, atomization and alienation in relation to public affairs, and on the other hand the aspiration of the individual to search for a community and support from others ${ }^{68}$.

At present, the process of building a civil society in Europe is facing considerable difficulties in the form of cultural, religious and ethnic diversity. The society, because of significant migration trends, separation from the nation state and the ease of moving from one culture to another, is becoming multicultural and multiethnic, bringing together people of different traditions, national identities, histories and cultures. The reduced importance of the nation-state, caused by the trends of globalization and integration, is now causing the disintegration of the previously coherent concepts of nation, state and culture. Therefore, we must today create a postnational society and a cultural pluralism that relates to every individual ${ }^{69}$.

A characteristic feature of the present postmodern era is that of subjecting the civil society to many dichotomous trends:

1) globalization and locality,

2) unification and diversity

An important trend, resulting from such dichotomous relationships, is the dynamics of change and the moral and ethical uncertainty caused by a lack of permanent values.

Globalization requires living together in a world of many races, religions and cultures. It creates a pluralism of values, behavior patterns and languages, but it also negates the existence of diverse lifestyles by imposing a certain way of life, work, etc. Globalization "diffuses" national consciousness, weakens the importance of the nation-state and its judicial and legislative competence, which are a visible sign of the state's identity. Hence, there appears another trend - locality. It results from the cultural changes and affects the participation of individuals in the social life of a particular area. Locality shows that all types of social associations and

\footnotetext{
${ }^{66}$ ibid 270.

${ }^{67}$ Dobrochna Bach-Dolecka, 'Jednostka jako centralny punkt odniesienia w europejskim i międzynarodowym porządku prawnym' in Mirosław Wyrzykowski (ed), Prawa staja się prawem. Status jednostki a tendencje rozwojowe prawa (Wydawnictwo LIBER 2006) 62.

68 See Zygmunt Bauman, Wieloznaczność nowoczesna - nowoczesność wieloznaczna, Roman Lis (tr) (Wydawnictwo Naukowe PWN 1995) 279.

69 See Robert Geisler, Granice pogranicza - wczoraj, dziś i jutro. Refleksja troche socjologiczna $\quad$ www.socjologia.ath.bielsko.pl/prace/konferencja.rgeisler.pdf; $\quad$ Leszek Gilejko, Globalizacja a zróżnicowanie społeczne we współczesnym świecie www.instytut.info/images/stories/ksiazki_polecane/17 kształcenie ustawiczne/11gilejko.pdf.
} 
institutions can operate independently from the state, although the ease of migration and free adaptation to new cultural conditions weakens their effectiveness (despite the formally existing legal framework and guarantees).

Society at the close of the $20^{\text {th }}$ and the beginning of the $21^{\text {st }}$ century is, in the spirit of postmodern theory, subject to strong pressures challenging the existing legal and social orders, traditions, rules and principles. This society is to move towards a radical pluralism and tolerance. It should be characterized by a spontaneous solidarity and a selfless attitude of caring about others. The postmodern society is also characterized by a revolutionary dynamic of change in many areas, and, at the same time, uncertainty caused by a crisis of values and strong ethical and moral challenges. Diversity, on the other hand, may have both a macrostructural (international, global) and microstructural (local, even individual) aspect. Diversity relates to wealth and the revolution of communication and information.

Globalization, possessing supranational references related to the functioning of supranational public institutions, political parties or corporations, at the same time questions the abilities and inclinations of a society regarding the development of public space via organized activity in order to realize group purposes. A conscious and voluntary withdrawal from entering public affairs is in the literature called interpassivity ${ }^{70}$. Globalization, however, cannot be entirely blamed for civil interpassivity and reserve towards public affairs. It seems that it is connected with a lack of responsibility within individuals and the reluctance to bear responsibility, as well as the lack of authority figures in public or spiritual life willing to act for the common good. This results in an attitude of distrust of individuals towards their legal institutions and political activities and reduces the individual sense of empowerment to make differences in solving social problems.

Globalization legitimizes individual entitlements, while also jeopardizing the common good. An increased focus on the individual destroys the integrity of the idea of citizenship, including the sense of nationality. Allowing an individual to function on a social level in a community that shapes attitudes, morality and identity guarantees public security and the realization of interests and aspirations of both individuals and the global community.

${ }^{70}$ Przedańska (n 1) 22. 